\title{
A Study of Ferrospheres in the Coal Fly Ash
}

\author{
Danzandorj Sunjidmaa1, Ganbat Batdemberel2 ${ }^{2}$, Shaikhslam Takibai ${ }^{3}$ \\ ${ }^{1}$ Department of Environmental Engineering, School of Civil Engineering and Architecture, MUST, Ulaanbaatar, Mongolia \\ ${ }^{2}$ Department of Physics, School of Applied Sciences, MUST, Ulaanbaatar, Mongolia \\ ${ }^{3}$ Pavlodar State University, Pavlodar, Republic of Kazakhstan \\ Email: *gdembee@must.edu.mn
}

How to cite this paper: Sunjidmaa, D., Batdemberel, G. and Takibai, S. (2019) A Study of Ferrospheres in the Coal Fly Ash. Open Journal of Applied Sciences, 9, 10-16. https://doi.org/10.4236/ojapps.2019.91002

Received: December 14, 2018

Accepted: January 15, 2019

Published: January 18, 2019

Copyright $\odot 2019$ by author(s) and Scientific Research Publishing Inc. This work is licensed under the Creative Commons Attribution International License (CC BY 4.0).

http://creativecommons.org/licenses/by/4.0/

Open Access

\begin{abstract}
Coal fly ash is an industrial by-product, produced from coal combustion in thermal power plants. It is the most complex anthropogenic materials, which consists of combination of minerals originated from different sources. Coal fly ash and its byproduct has become an environmental concern over the World. Therefore, there is a pressing and ongoing need to investigate the structures and some properties of coal fly ash and develop new recycling methods for it. The amount of silica, aluminum, calcium, potassium, magnesium, sodium, titanium and phosphorus oxides contained in power plant fly ash was determined by X-ray flouresecence (XRF) analysis. Concentration of heavy metals in fly ash was in sequence of $\mathrm{Pb}>\mathrm{Zn}>\mathrm{Cu}>\mathrm{Cr}>\mathrm{Ni}$. As results of Scanning Electron Microscopy (SEM), except for porous and hollow particles, large and small microspheres were observed. These particles are classified as ferrospheres. X-ray diffraction (XRD) analysis show that fly ash consists of the following crystal phases: quartz, albite, anorthite and hematite.
\end{abstract}

\section{Keywords}

Fly Ash, Ferrospheres, Quartz, Albite, Anorthite, Hematite

\section{Introduction}

Fly ash was firstly used as mineral filler in road pavement in 1930. The "Fly ash" contained in concrete was published in a research paper of Concrete Institute of USA in 1937. Today, electric utilities in the US annually burn billion tons of coal and generate over 100 million tons of large-volume coal combustion products. Only a quarter of these coal combustion products are used and others are stored underground. Utilization of coal combustion products have following results: 1) Reducing land degradation, 2) Saving environmental resource, 3) Harmless effect in environment, 4) Decreasing carbon dioxide, 5) User-saving, 6) Decreas- 
ing price of electricity. These results are the world tendencies to use coal combustion products and slag [1]. The chemical elements, mineral composition, particle forming condition and physical chemical properties of fly ash have been studied by SEM [2] [3]. The fly ash container of Thermal Power Plant III, Ulaanbaatar city, Mongolia will be filled to capacity in the coming years; therefore it is a good opportunity to study for ways to reuse the fly ash as a raw resource for roads, building material or agriculture and to verify if the power plant has changed its combustion procedure. Power Plant III burns brown coal from Baganuur, this coals general properties are: humidity: $28 \%-33 \%$, ash-flow: $15 \%$ - 20\%, calorie: 3300 - 44,200 kcal/kg, sulfur: $0.7 \%$ - $0.8 \%$. The physical and chemical properties of Baganuur coal deposit make it usable exclusively for Thermal Power Plants and also with processing it has been proven through research that it can be used for syngas, liquid and patent fuel, and raw materials for the chemical industry. The properties of fly ash depend heavily on the coal mine, mode of operation and other parameters.

The main objective of this research is focused on the obtaining new types of materials with the use of modern technological methods (for example, bricks, lightweight concrete, geopolymer and etc.) based on the detailed structural analysis of the ferrospheres from coal fly ash-industrial byproduct materials and further develop technological backgrounds of it.

\section{Experimental}

\subsection{XRF Analysis}

Sample was measured by X-ray Fluorescence Spectrometer (Rigaku, ZXS Primus II). Results of the analysis are shown in Table 1.

As can be seen in Table 1, fly ash contains silicon dioxide (62.53\%), aluminum oxide $(15.36 \%)$, calcium oxide $(8.84)$, ferric oxide $(5.84 \%)$, potassium oxide $(2.26 \%)$, magnesium oxide $(1.33 \%)$, sodium oxide $(1.04 \%)$, titanium dioxide $(0.61 \%)$, manganese oxide $(0.11 \%)$, phosphorus oxide $(0.08 \%)$ respectively. Except for these elements, low content of (ppm) Sr, $\mathrm{Ba}, \mathrm{Zr}, \mathrm{Pb}, \mathrm{Rb}, \mathrm{Zn}, \mathrm{Cu}, \mathrm{Cr}, \mathrm{Y}$, $\mathrm{Ni}, \mathrm{Co}$, Th, $\mathrm{Ga}$ and $\mathrm{Nb}$ were observed. Among these elements, $\mathrm{Pb}, \mathrm{Zn}, \mathrm{Cu}, \mathrm{Cr}$, $\mathrm{Co}, \mathrm{Ni}$ are considered seriously. On the other hand, a sample of the fly ash is classified as $\mathrm{F}$ class, because silicon oxide, aluminum oxide and iron oxide are contained more than $70 \%$ of the ash (according to the ASTM C 618 standard).

Table 1. Chemical composition of coal fly ash.

(a)

\begin{tabular}{lccccccccc}
\hline Compounds & $\mathrm{SiO}_{2}$ & $\mathrm{Al}_{2} \mathrm{O}_{3}$ & $\mathrm{CaO}$ & $\mathrm{K}_{2} \mathrm{O}$ & $\mathrm{MgO}$ & $\mathrm{Na}_{2} \mathrm{O}$ & $\mathrm{TiO}_{2}$ & $\mathrm{MnO}$ & $\mathrm{P}_{2} \mathrm{O}_{5}$ \\
\hline Value, wt. \% & 62.53 & 15.36 & 8.84 & 2.26 & 1.33 & 1.04 & 0.61 & 0.11 & 0.08 \\
\hline
\end{tabular}

(b)

\begin{tabular}{cccccccccccccc}
\hline Elements & $\mathrm{Sr}$ & $\mathrm{Ba}$ & $\mathrm{Zr}$ & $\mathrm{Pb}$ & $\mathrm{Zn}$ & $\mathrm{Cu}$ & $\mathrm{Cr}$ & $\mathrm{Y}$ & $\mathrm{Ni}$ & $\mathrm{Co}$ & $\mathrm{Th}$ & $\mathrm{Ga}$ & $\mathrm{Nb}$ \\
\hline Value, ppm & 518 & 461 & 166 & 132 & 69 & 47 & 47 & 37 & 31 & 26 & 23 & 18 & 14 \\
\hline
\end{tabular}


This fly ash is pozzolanic in nature, and contains less than $7 \%$ lime $(\mathrm{CaO})$. Since the calcium oxide content of this sample was higher than $7 \%(\mathrm{CaO}, 8.84 \mathrm{wt} . \%)$ this sample is might to be defined to be the C Class fly ash. This class is formed when burning younger lignite or sub-bituminous coal [4].

\subsection{SEM Analysis}

SEM (Energy dispersive $\mathrm{x}$-ray spectroscopy (EDX)) was applied to characterize the form of the fly ash particles. Results are depicted in Figures 1-3.

Except for porous large particles, individual large and small microspheres were observed in fly ash (Figure 1). As a result of analysis of microsphere A (marked red in Figure 1), following elements were determined (Figure 2).

As can be seen in Figure 2, microsphere A contains Ca (11.5 wt. \%), Si (34.8 wt. \%), Al (10.3 wt. \%), Fe (43.4 wt. \%). Therefore this sphere can be called a ferroshperes.

Except for porous large particles, individual large and small microspheres and hollow microspheres were observed in fly ash (Figure 3). As a result of analysis of porous sphere B (marked red in Figure 3), following elements were determined (Figure 4).

As can be seen in Figure 4, porous sphere B contains Fe (75.3 wt. \%), Si (11.1 wt. \%), Ca (4.1 wt. \%), Br (9.4 wt. \%).

Except for hollow large particles, individual large and small microspores were observed in fly ash (Figure 5). As a result of analysis of hollow particles C (marked red in Figure 5), following elements were determined (Figure 6).

As can be seen in Figure 6, hollow particle C contains Fe (47.1 wt. \%), Si (30.3 wt. \%), $\mathrm{Ca}$ (13.6 wt. \%), $\mathrm{Al}(9.0$ wt. \%). As mentioned before this sphere can be

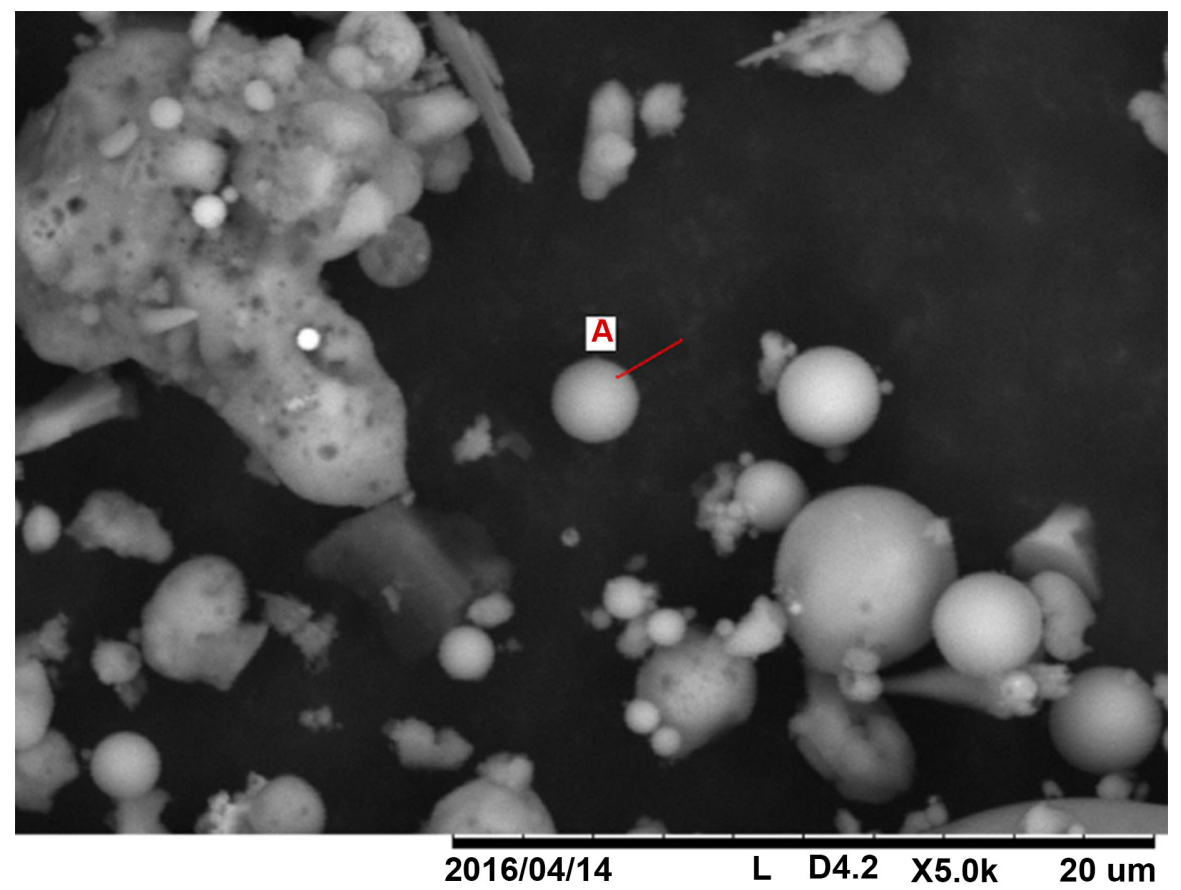

Figure 1. SEM micrograph of Coal fly ash $(20 \times \mu \mathrm{m})$. 


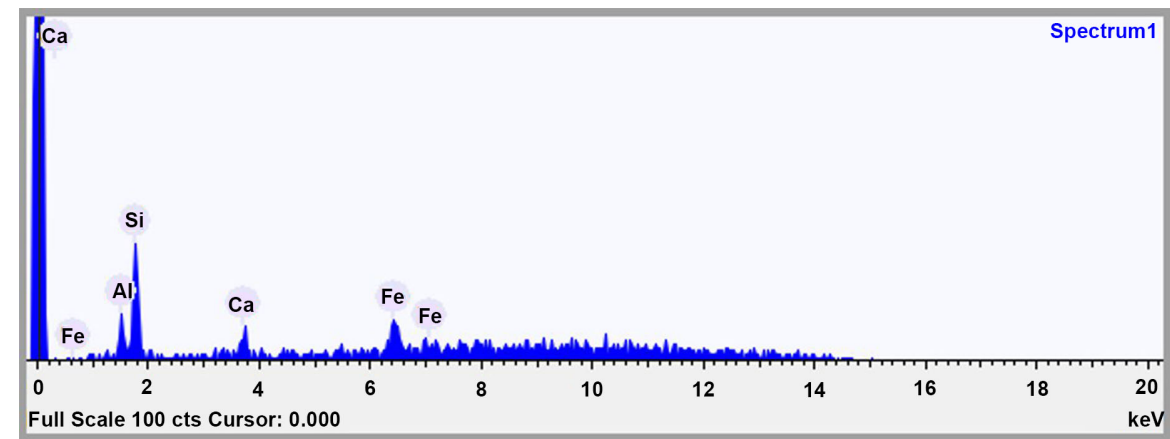

Figure 2. Chemical elements of individual microsphere A.

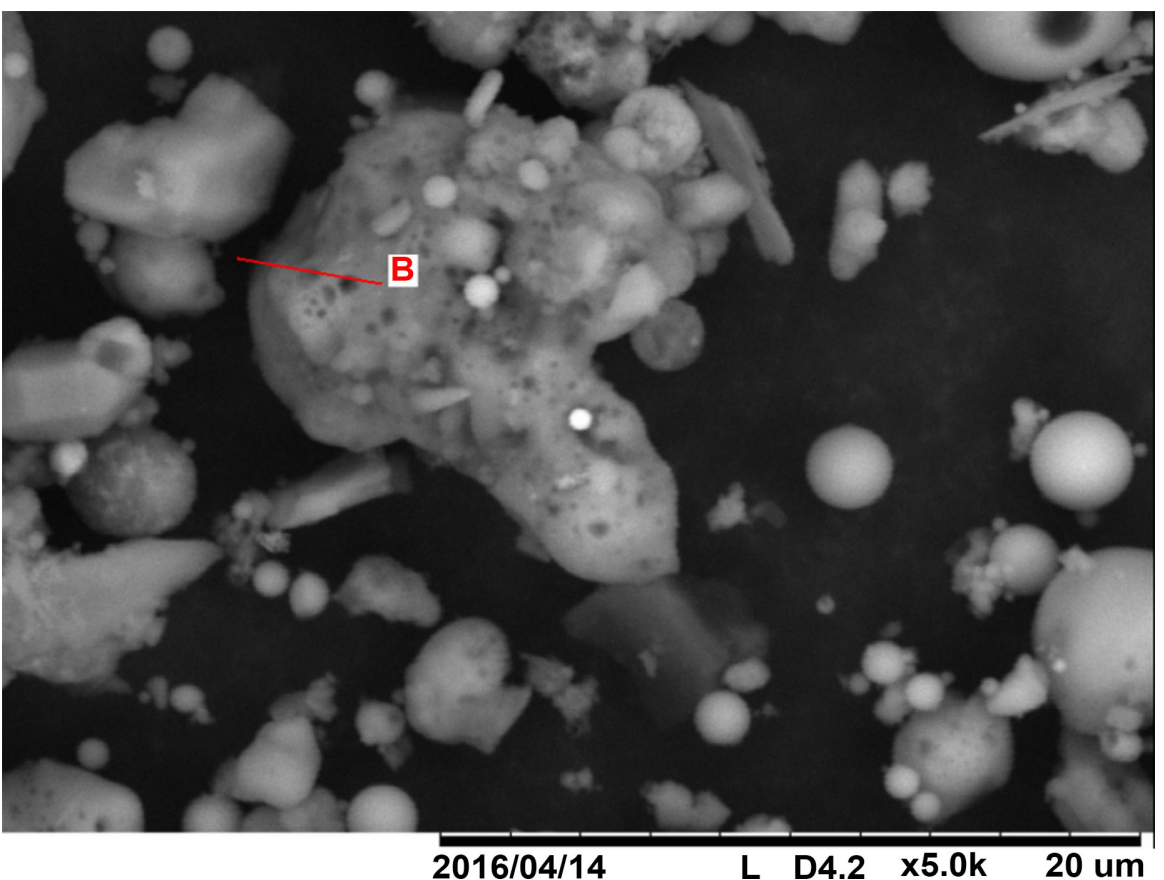

Figure 3. SEM micrograph of fly ash $(20 \times \mu \mathrm{m})$.

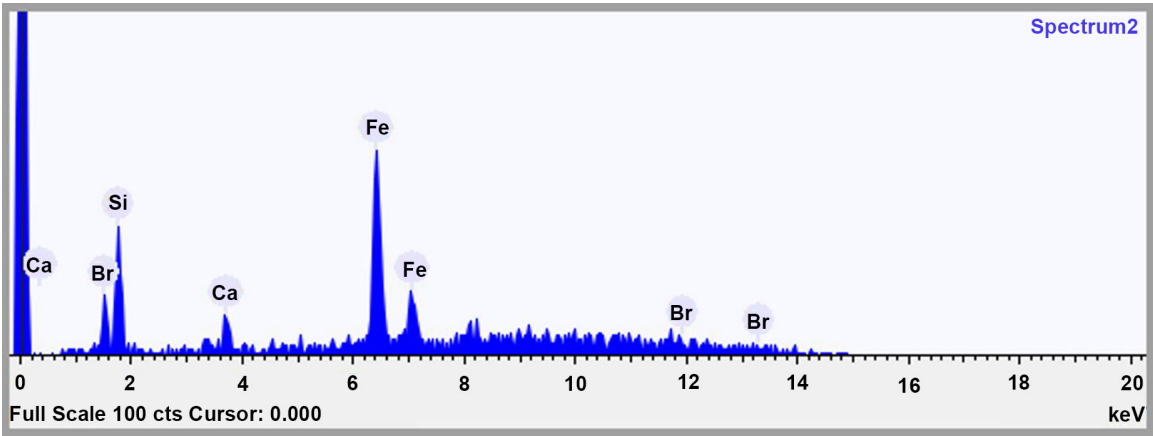

Figure 4. Chemical elements of porous sphere B.

also called a ferroshperes. On the basis of the analysis, it can be said that, the main component of all microspheres are iron ( $\mathrm{Fe}=43-75 \mathrm{wt} . \%)$. Other components are $\mathrm{Ca}(4-13 \mathrm{wt} . \%), \mathrm{Si}(11$ - $35 \mathrm{wt} . \%), \mathrm{Al}(9-10 \mathrm{wt} . \%)$. These observed particles are in agreement with other researcher's investigation [2] [3]. 


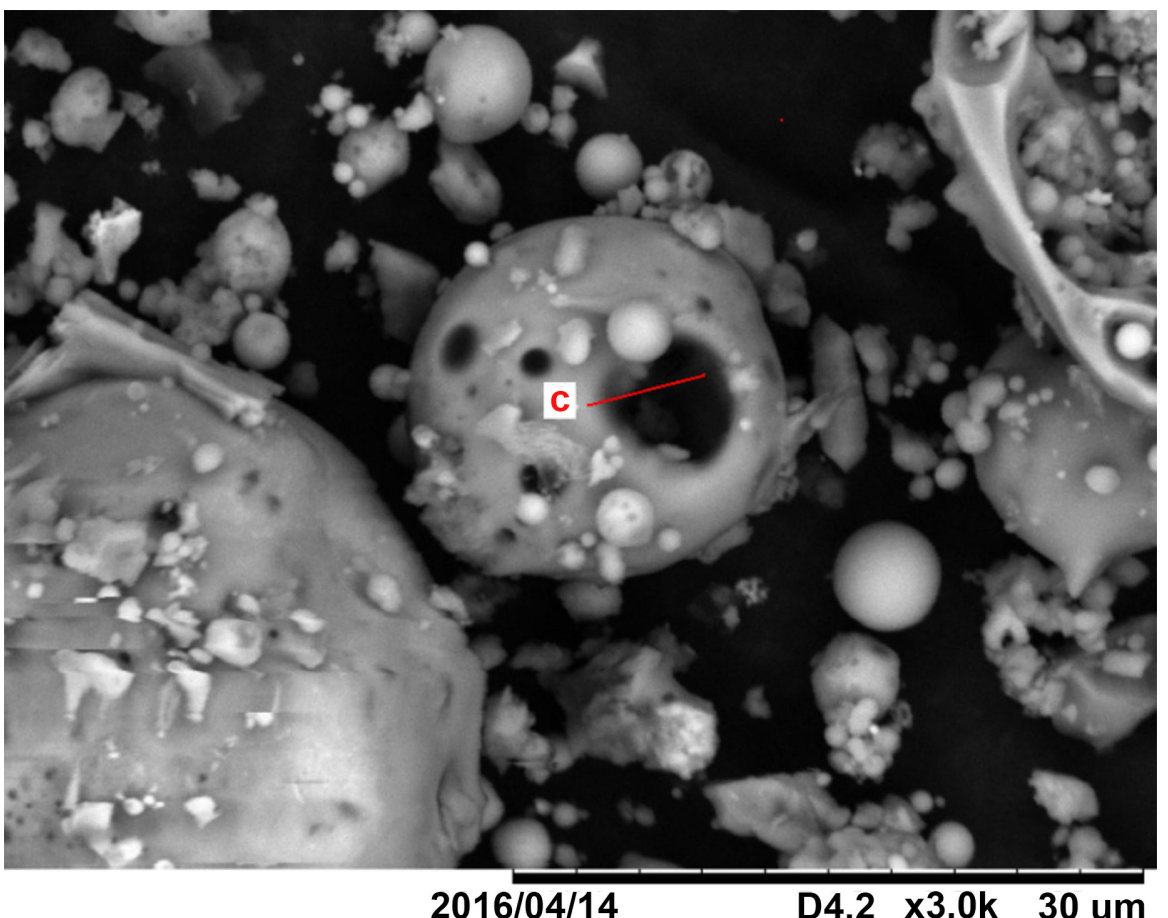

Figure 5. SEM micrograph of fly ash $(20 \times \mu \mathrm{m})$.

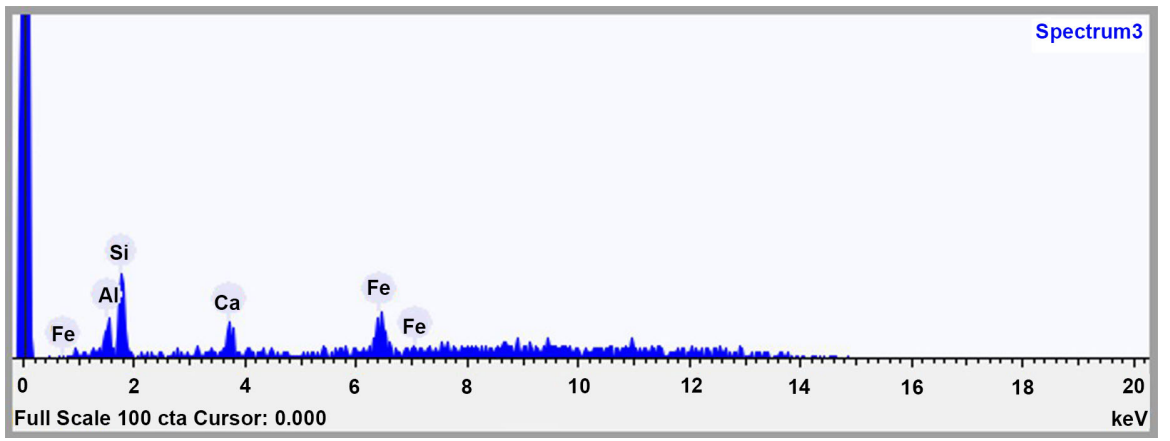

Figure 6. Chemical elements of hollow sphere C.

\subsection{XRD Measurements}

$\mathrm{XRD}$ measurements were carried out at ambient conditions on a X-ray powder diffractometer (Enraf Nonius Delft Diffractis 583). A step size of $0.05^{\circ} 2 \Theta$, an integration time of was $2 \mathrm{~s}$ per step and scan range from $13^{\circ}$ to $80^{\circ}$ were used. Phase analysis was done by < Match! Crystal Impact > program [5]. The x-ray powder diffraction pattern of samples is shown in Figure 7.

The interatomic distances was calculated by using equation $2 \mathrm{~d} \sin \Theta=\mathrm{n} \lambda$ and compared to International Powder Diffraction File (ICSD, PDF-4). Then types of minerals and amounts were determined (Table 2).

As can be noticed (Table 2), crystal phase of fly ash consists of $54.74 \%$ of $\alpha$-quartz $\mathrm{SiO}_{2}, 27.55 \%$ of monoclinic albite $\left(\mathrm{K}\left[\mathrm{AlSi}_{3}\right] \mathrm{O}_{8}\right), 9.21 \%$ of monoclinic anorthite $\mathrm{Ca}\left(\mathrm{Al}_{2} \mathrm{Si}_{2} \mathrm{O}_{8}\right), 8.49 \%$ of rhombohedral hematite $\left(\alpha-\mathrm{Fe}_{2} \mathrm{O}_{3}\right)$ respectively. The iron oxide is detected by hematite. However, low content of $\mathrm{K}, \mathrm{Mg}, \mathrm{Ti}, \mathrm{Mn}$, 


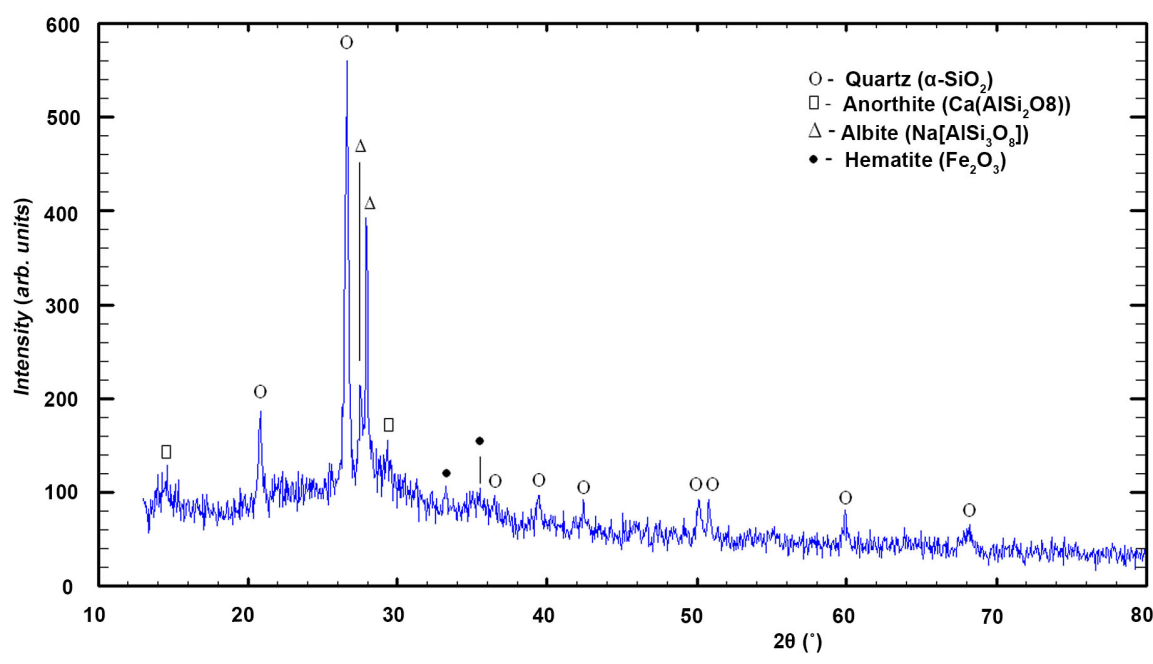

Figure 7. X-ray pattern of burned coal.

Table 2. Phase composition and crystal structural parameters of coal fly ash.

\begin{tabular}{|c|c|c|c|c|c|}
\hline $\mathrm{N}$ & 2-theta & $\mathrm{d}, \AA$ & Minerals & $\begin{array}{l}\text { Chemical formula and } \\
\text { amount of minerals }\end{array}$ & $\begin{array}{l}\text { Crystal symmetry, space group } \\
\text { and lattice parameters }(\AA)\end{array}$ \\
\hline 1 & 20.83 & 4.25 & & $\mathrm{SiO}_{2}$ & \\
\hline 2 & 26.19 & 3.34 & Quartz & $\mathrm{SiO}_{2}$ & $\begin{array}{c}\text { Hexagonal, } \mathrm{P}_{2} 2_{1}, \mathrm{a}=4.91 \\
\mathrm{c}=5.40\end{array}$ \\
\hline 3 & 27.50 & 3.23 & & $\mathrm{Na}\left[\mathrm{AlSi}_{3} \mathrm{O}_{8}\right]$ & \\
\hline 4 & 27.87 & 3.19 & Albite & $\mathrm{Na}\left[\mathrm{AlSi}_{3} \mathrm{O}_{8}\right](27.55 \%)$ & \\
\hline 5 & 29.44 & 3.03 & Anorthite & $\begin{array}{c}\mathrm{Ca}\left(\mathrm{Al}_{2} \mathrm{Si}_{2} \mathrm{O}_{8}\right) \\
(9.21 \%)\end{array}$ & $\begin{array}{l}\text { Monoclinic, } \mathrm{I}(-1), \mathrm{a}=8.18 \\
\quad \mathrm{~b}=12.86, \mathrm{c}=14.16\end{array}$ \\
\hline 6 & 33.12 & 2.70 & Hematite & $\begin{array}{l}\alpha-\mathrm{Fe}_{2} \mathrm{O}_{3} \\
(8.49 \%)\end{array}$ & $\begin{array}{l}\text { Rhombohedral, } \mathrm{R}(-3) \mathrm{c} \\
\mathrm{a}=5.03, \mathrm{c}=13.74\end{array}$ \\
\hline 7 & 35.48 & 2.52 & & $\alpha-\mathrm{Fe}_{2} \mathrm{O}_{3}$ & \\
\hline 8 & 36.38 & 2.45 & & $\mathrm{SiO}_{2}$ & \\
\hline 9 & 39.37 & 2.28 & & $\mathrm{SiO}_{2}$ & \\
\hline 10 & 42.36 & 2.12 & & $\mathrm{SiO}_{2}$ & \\
\hline 11 & 50.00 & 1.81 & & $\mathrm{SiO}_{2}$ & \\
\hline 12 & 50.69 & 1.79 & & $\mathrm{SiO}_{2}$ & \\
\hline 13 & 59.86 & 1.54 & & $\mathrm{SiO}_{2}$ & \\
\hline 14 & 67.44 & 1.36 & & $\mathrm{SiO}_{2}$ & \\
\hline
\end{tabular}

2-theta-scattering angle, $\mathrm{d}-$ interatomic distances.

$\mathrm{P}, \mathrm{Sr}, \mathrm{Ba}, \mathrm{Zr}, \mathrm{Pb}, \mathrm{Rb}, \mathrm{Zn}, \mathrm{Cu}, \mathrm{Y}, \mathrm{Ni}, \mathrm{Co}$, Th, $\mathrm{Ga}$ and $\mathrm{Nb}$ elements were observed in results of XRF analysis, these elements does not form crystal phase in results of XRD analysis, because of equipment resolution. The results of XRD measurements are in agreement with chemical analysis (Table 1).

The above-described phases of albite and anorthite are quite stable and ordered compounds. From these perspectives, these phases are used to be as not only filler materials in concrete but also applied for the strengthening the 
concrete. The results of x-ray phase analysis made on coal fly ash were in good agreement with the results from the investigations within the frame of the Project "Utilization of Coal Fly Ash" realized at Florida University in 1992 [1].

\section{Conclusions}

As a result, it can be concluded that

- Baganuur coal ash that are used at the Thermal Power Plant III of Ulaanbaatar city, Mongolia contains $8.84 \mathrm{wt} \%$ of calcium oxide $(\mathrm{CaO})$, it can be classified as C Class fly ash. Therefore, due to its low content of calcium this type of fly ash is possible for use of the production of geopolymer material.

- However, according the US standard ASTM C 618, this type of fly ash is defined to be classified to be F Class fly ash.

- Microspheres in the coal fly ash samples were successfully observed by the SEM method. Since these microspheres contain a large amount of iron (Fe, $43-75 \mathrm{wt} \%$ ) it is possible to separate them with magnetic separation method.

$\mathrm{X}$-ray diffraction analysis shows that the major compound, which represents the iron phase in microspheres are the hematites $\left(\alpha-\mathrm{Fe}_{2} \mathrm{O}_{3}, 8.49 \mathrm{wt} \%\right)$.

\section{Conflicts of Interest}

The authors declare no conflicts of interest regarding the publication of this paper.

\section{References}

[1] Openshaw, S.C., Miller, W.L., Bolch, W.E. and Bloomquist, D. (1992) Utilization of Coal Fly Ash. State University System of Florida, Florida Center for Solid and Hazardous Management, Gainesville.

[2] Sokol, E.V., Maksimova, N.V., Volkova, N.I., Nigmatulina, E.N. and Frenkel, A.E. (2000) Hollow Silicate Microspheres from Fly Ashes of the Chelyabinsk Brown Coals (South Urals, Russia). Fuel Processing Technology, 67, 35-52. https://doi.org/10.1016/S0378-3820(00)00084-9

[3] Sokol, E.V., Kalugin, V.M., Nigmatulina, E.N., Volkova, N.I., Frenkel, A.E. and Maksimova, N.V. (2002) Ferrosphers from Fly Ashes of Chelyabinsk Coals: Chemical Composition, Morphology and Formation Conditions. Fuel, 81, 867-876. https://doi.org/10.1016/S0016-2361(02)00005-4

[4] Schert, J., Townsend, T. and Wu, C.-Y. (2012) Identification of Potential Concerns Associated with FDOT Use of Ammoniated Fly Ash. Hinkley Center for Solid and Hazardous Waste Management, Gainesville.

[5] Putz, H. and Brandenburg, K. Phase Indentification Form Powder Diffraction (Match!). Version 1.11. Bonn. 